\title{
Ethylene and methane in the upper water column of the subtropical Atlantic
}

\author{
RICHARD SEIFERT, NIKOLAI DELLING, HANS HERMANN \\ RICHNOW, STEPHAN KEMPE*, JENS HEFTER \& WALTER \\ MICHAELIS \\ Institut für Biogeochemie und Meereschemie, Universität Hamburg, Bundesstr. 55, \\ D-21046 Hamburg, Germany; * Geologisch-Paläontologisches Institut, \\ Technische Hochschule Darmstadt, Schnittbahnstr. 9, D-64287 Darmstadt
}

Accepted 31 March 1998

Key words: Atlantic, ethylene, methane, sea-air exchange

\begin{abstract}
The vertical distributions of ethylene and methane in the upper water column of the subtropical Atlantic were measured along a transect from Madeira to the Caribbean and compared with temperature, salinity, oxygen, nutrients, chlorophyll-a, and dissolved organic carbon (DOC).

Methane concentrations between 41.6 and $60.7 \mathrm{~nL} \mathrm{~L}^{-1}$ were found in the upper $20 \mathrm{~m}$ of the water column giving a calculated average flux of methane into the atmosphere of $0.82 \mu \mathrm{g}$ $\mathrm{m}^{-2} \mathrm{~h}^{-1}$. Methane profiles reveal several distinct maxima in the upper $500 \mathrm{~m}$ of the water column and short-time variations which are presumably partly related to the vertical migration of zooplankton.

Ethylene concentrations in near surface waters varied in the range of 1.8 to $8.2 \mathrm{~nL} \mathrm{~L}^{-1}$. Calculated flux rates for ethylene into the atmosphere were in the range of 0.41 to $1.35 \mu \mathrm{g}$ $\mathrm{m}^{-2} \mathrm{~h}^{-1}$ with a mean of $0.83 \mu \mathrm{g} \mathrm{m}^{-2} \mathrm{~h}^{-1}$. Maximum concentrations of up to $39.2 \mathrm{~nL} \mathrm{~L}^{-1}$ were detected directly below the pycnocline in the western Atlantic. The vertical distributions of ethylene generally showed one maximum at the pycnocline (about $100 \mathrm{~m}$ depth) where elevated concentrations of chlorophyll-a, dissolved oxygen, and nutrients were also found; no ethylene was detected below $270 \mathrm{~m}$ depth. This suggests that ethylene release is mainly related to one, probably phytoplankton associated, source, while for methane, enhanced net production occurs at various depth horizons. For surface waters, a simple correlation between ethylene and chlorophyll-a or DOC concentrations could not be observed. No considerable diurnal variation was observed for the distribution and concentration of ethylene in the upper water column.
\end{abstract}

\section{Introduction}

Organic compounds in the Earth's atmosphere are quantitatively dominated by hydrocarbons, the most abundant being methane. The increasing concentration of these greenhouse gases and their strong influence on tropospheric 
and stratospheric chemistry call for endeavours to understand the processes which control these components. Recent studies indicate a considerable influence of atmospheric methane concentrations on Holocene climatic variations (Stauffer et al. 1988; Chappellaz et al. 1993). At present, tropospheric methane concentrations are increasing annually by 0.7 to $1.4 \%$ (Rasmussen \& Khalil 1984; Khalil \& Rasmussen 1986; Steele et al. 1987, 1992). This increase is attributed to anthropogenically mediated release and a decrease of oxidation by $\mathrm{OH}$-radicals in the atmosphere (Cicerone \& Oremland 1988).

According to several studies that found concentrations of dissolved methane and ethylene exceeding atmospheric equilibrium in marine surface waters, the ocean is suggested to be a natural source for atmospheric methane and ethylene (Lamontagne et al. 1974; Brooks et al. 1981; Conrad \& Seiler 1988; Plass et al. 1992; Plass-Dülmer et al. 1993, 1995). In some places, elevated dissolved gas concentration can be attributed to anthropogenic activity, e.g. offshore oil and gas production in shelf areas (Brooks \& Sackett 1973). Advection of methane enriched coastal waters (Scranton \& Farrington 1977; De Angelis \& Lilley 1987; Cynar \& Yayanos 1992) and riverine influence (Jones \& Amador 1993) are also relevant processes. For the open ocean, biological in situ production is assumed to cause elevated methane concentrations in the upper water column $<500 \mathrm{~m}$ (Lamontagne et al. 1973; Scranton \& Brewer 1977; Traganza et al. 1979; Burke et al. 1983; Owens et al. 1991). Compared to a global methane input to the atmosphere of about $540 \mathrm{Tg} \mathrm{a}^{-1}$, methane release from the ocean is modest and suggested to be in the range of 3 to $18 \mathrm{Tg} \mathrm{a}^{-1}$ (Conrad \& Seiler 1988; Khalil \& Rasmussen 1983; Bange et al. 1994).

Non-methane-hydrocarbons of carbon chain length from $\mathrm{C}_{2}$ to $\mathrm{C}_{6}$ (NMHC) are known to be of considerable relevance to atmospheric chemistry due to their chemical reactivity (e.g. Rudolph \& Ehhalt 1981; Greenberg \& Zimmermann 1984, Bonsang et al. 1991). The ocean is believed to have a major influence on atmospheric NMHC concentrations at least for remote regions, and ethylene was found to be the most prominent NMHC in ocean surface waters (Swinnerton \& Lamontagne 1974; Bonsang et al. 1988; PlassDülmer et al. 1993, 1995). Sawada and Totsuka (1986) estimate the global emission of ethylene to be $18-45 \mathrm{Tg} \mathrm{a}^{-1}$, of which $74 \%$ is released from natural and $26 \%$ from anthropogenic sources; $11 \%$ of the natural emission $\left(2.16-4.95 \mathrm{Tg} \mathrm{a}^{-1}\right)$ is from aquatic ecosystems. Their calculation for the ocean is based on data from Swinnerton and Lamontagne (1974) and Lamontagne et al. (1975). Recently, the emission of ethylene from the global ocean was calculated to be in the range of 0.89 to $2.17 \mathrm{~g} \mathrm{Tg} \mathrm{a}^{-1}$ in a study on NMHC including most of the earlier published data (Plass-Dülmer et al. 1995). 


\section{Samples and methods}

The data on the vertical distribution of methane and ethylene in the subtropical Atlantic discussed in this paper were collected in December 1991 on cruise SO 76A of R/V SONNE as part of the Joint Global Ocean Flux Study (JGOFS). The scope of this cruise was to study the exchange of carbon dioxide and light hydrocarbons between ocean and atmosphere on a transect from Madeira to Panama.

Water samples were taken in December 1991 at 11 locations along a transect from $31: 17.5^{\circ} \mathrm{N}, 21: 59,3^{\circ} \mathrm{W}$ to $13: 50.0^{\circ} \mathrm{N}, 74: 04.1^{\circ} \mathrm{W}$ (Figure 1). One location in the West Atlantic was covered three times within an interval of 8 hours to study diurnal variations. Sampling was performed by a rosette sampler equipped with 12 5-L Niskin bottles (Hydro Bios) and a multiprobe system recording pressure, temperature, conductivity and oxygen (ME Kiel). Water for hydrocarbon analyses was transferred via gas tight PVC tubes from the Niskin bottles into $600 \mathrm{~mL}$ glass bottles directly after the rosette sampler was recovered on board. Bottles were closed gas tight and head space free with a Teflon cap and stored into cold $\left(4{ }^{\circ} \mathrm{C}\right)$ and dark. Analysis was performed within 8 hours of sampling. Dissolved hydrocarbons were determined using an onboard stripping-trapping technique (Michaelis et al. 1990) modified from the method described by Swinnerton and Linnenbom (1967). Briefly, the sample bottles are attached to the purge system via a Teflon cone with stainless steel capillaries that allow the sample to be introduced into the glass stripping chamber by the pressure from a helium gas server. After a $500 \mathrm{~mL}$ sample has been transferred, the water is stripped for 30 minutes with a helium flow of $40 \mathrm{~mL} \mathrm{~min}{ }^{-1}$. The trap system consists of two traps, the first trap, filled with activated $\mathrm{Al}_{2} \mathrm{O}_{3}$, retains all hydrocarbons except methane and the second trap, filled with activated charcoal, adsorbs methane. The dimension of both traps is $150 \mathrm{~mm} \times 2 \mathrm{~mm}$. During the stripping procedure, the trap system is cooled in an acetone bath at $-85^{\circ} \mathrm{C}$. After stripping, the helium flow is switched to a back-flush mode and the target compounds are stripped into the gas chromatograph by heating the traps stepwise to $90^{\circ} \mathrm{C}$. In the first step, hydrocarbons are released from the $\mathrm{Al}_{2} \mathrm{O}_{3}$ trap and completely analysed. In the second step methane is stripped from the carbon trap and analysed. All helium, prior to entering the system, is passed through a $\mathrm{Al}_{2} \mathrm{O}_{3}$ column immersed in an acetone bath at $-85{ }^{\circ} \mathrm{C}$ to remove any trace gases of hydrocarbons. The gas chromatograph (CARLO ERBA Fractovap 4200) was equipped with an activated $\mathrm{Al}_{2} \mathrm{O}_{3}$ column $(3 \mathrm{~m} \times 4 \mathrm{~mm})$ and a flameionisation detector. The oven temperature was maintained at $120{ }^{\circ} \mathrm{C}$ that allows separation of saturated and unsaturated $\mathrm{C}_{2}$ to $\mathrm{C}_{4}$ hydrocarbons. An integrator (HEWLETT-PACKARD 3390A) was used to calculate peak areas. 


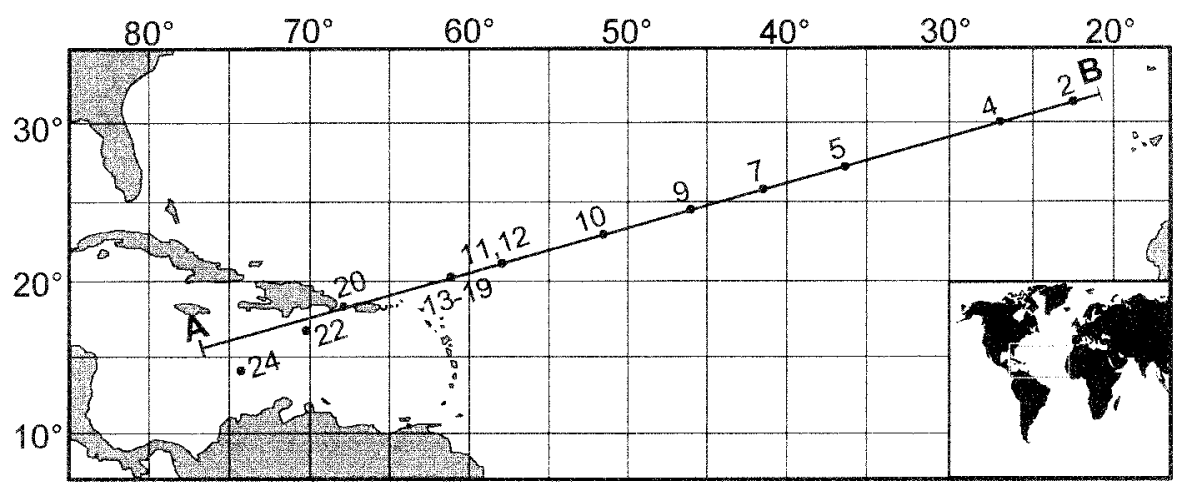

Figure 1. Map of cruise track and sampling points.

Commercial standards (LINDE) were used for quantification. The detection limit for methane and ethylene was $0.5 \mathrm{~nL} \mathrm{~L}^{-1}$; the precision was $\pm 5 \%$.

Methane fluxes from ocean to atmosphere were calculated applying the relationship given by Liss and Merlivat (1986) corrected according to the Schmidt numbers of methane and carbon dioxide as given by Lambert and Schmidt (1993). Atmospheric methane concentrations were compiled based on data given by Dlugokencky et al. (1994) using monthly means of December 1991 at the Azores, Barbados, Bermuda, and Izana. Pressure, wind speed, and water temperature were recorded at each station (Table 1). For chlorophyll-a determinations $2 \mathrm{~L}$ of water were filtered (Whatman $\mathrm{GF} / \mathrm{C}, 25 \mathrm{~mm}$ diameter). The filter was extracted (acetone: $\mathrm{H}_{2} \mathrm{O}$, v:v, 9:1) using ultrasonification and the extract was analysed by fluorescence spectrometry (Kontron, exitation wave-length: $420 \mathrm{~nm}$, emission wave-length: 590-750 nm).

\section{Results}

In the Atlantic, the highest methane concentrations were mostly found at about $100 \mathrm{~m}$ depth and appear to be higher to the west (Figure 2). Only stations 2 and 7 did not show a methane maximum near $100 \mathrm{~m}$ depth. These stations are also the only two where the surface water concentrations were below atmospheric equilibrium. In general, methane concentrations decreased with depth, reaching a concentration between 10 and $20 \mathrm{~nL} \mathrm{~L}^{-1}$ below $800 \mathrm{~m}$. These values exceed the background of about $5 \mathrm{~nL} \mathrm{~L}^{-1}$ found in deeper Indian and Pacific ocean waters (e.g. Atkinson \& Richards 1967; Michaelis et al. 1990; Plüger et al. 1990; Stüben et al. 1992). This difference might be caused by the younger age of he Atlantic deep water (Scranton \& 


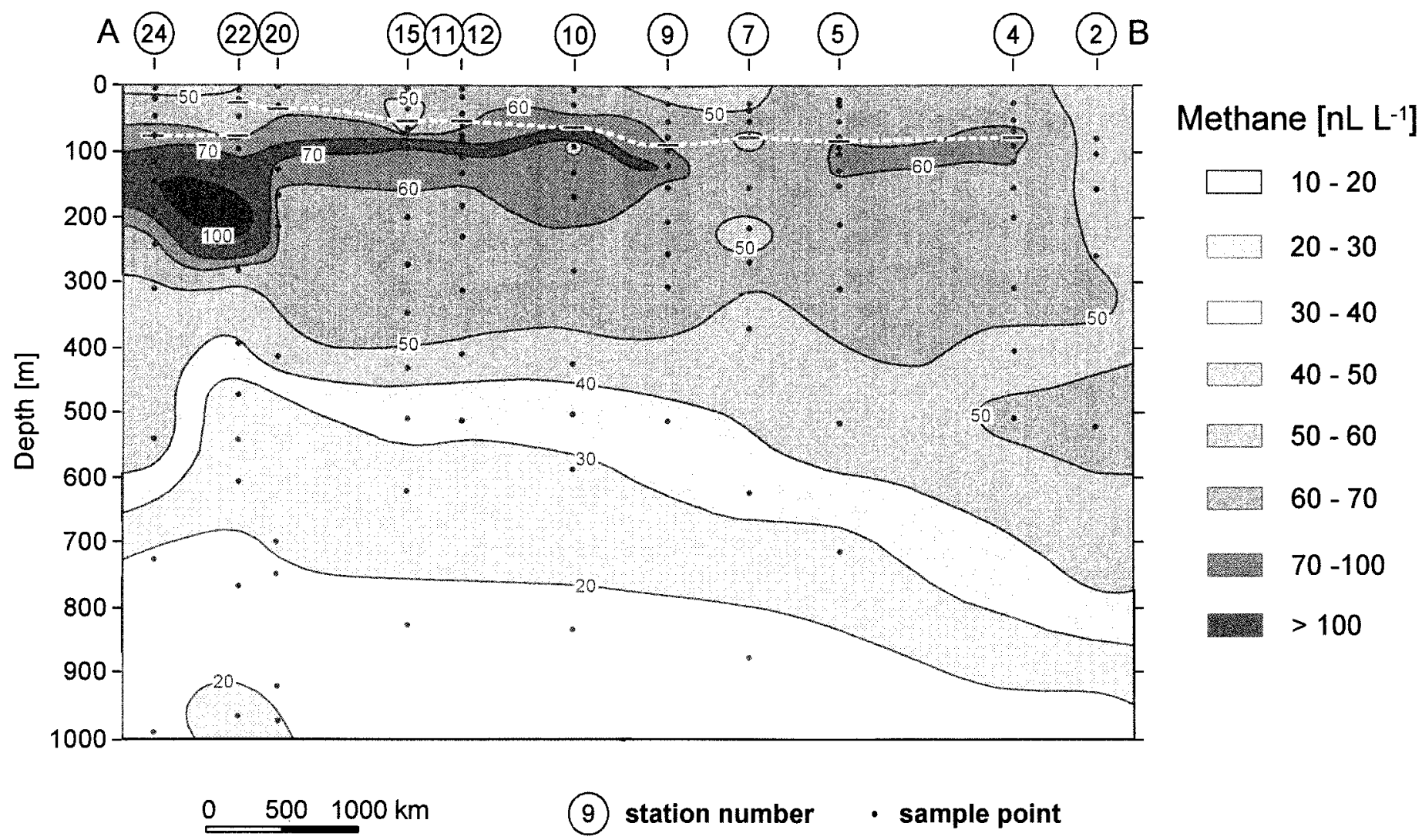

Figure 2. Concentrations of dissolved methane in the upper water column along the A-B profile (Figure 1). Station numbers are indicated above the profiles respectively. The upper edge of the pycnocline identified by density profiles (Sigma-T) is marked by white framed dashes. 
Brewer 1978). In the Mona Passage and the Caribbean, an increase in concentration is observed below $900 \mathrm{~m}$. This is assumed to be related to methane released from sediments at these near shore stations. Concentrations and distribution of dissolved methane in the upper water column in the Caribbean (stations 22-24) were also distinct from those of the West Atlantic. The methane maximum in the former was higher, at greater depth, and regionally more extended.

Dissolved ethylene was observed at all stations (Figure 3). Generally, the highest concentrations were present near the pycnocline slightly above the methane maximum and no ethylene was detected below $270 \mathrm{~m}$ depth. Highest concentration of ethylene appeared in the Central and West Atlantic stations (stations 9-20) reaching $40 \mathrm{~nL} \mathrm{~L}^{-1}$ at station 11/12. Unlike methane, ethylene concentrations did not increase in the Caribbean and showed only one, distinct maximum. Increased ethylene concentrations in the uppermost waterbody, that one might expect from light induced ethylene production (Wilson et al. 1970; Lee \& Baker 1992; Ratte et al. 1993; see discussion below) does not appear in any of the profiles depicted in Figure 3, even though they all were sampled during daytime.

To test whether there is a correlation between the concentrations of ethylene and the presence of phytoplankton (see discussion below), we determined chlorophyll-a concentrations (Figure 4). Enhanced concentrations were observed at about $100 \mathrm{~m}$ depth, where ethylene and methane were also enriched, and minor chlorophyll-a concentrations at surface waters at station 11/12 coincided with low ethylene concentrations. However, the regional distribution of chlorophyll-a was not well correlated with methane or ethylene.

Light induced production of $\mathrm{C}_{2}$ - and $\mathrm{C}_{3}$-alkenes from dissolved organic matter (DOC) in sea water has been proposed by several authors (Wilson et al. 1970; Lee \& Baker 1992; Ratte et al. 1993; Plass-Dülmer et al. 1995; see discussion). In our case, comparison of DOC (Fengler 1995; DOC was analysed using high temperature combustion in an oxygen atmosphere at a platinum catalyst) and ethylene concentrations for 58 samples (Figure 5) indicates that there is no simple relationship between these parameters. Even the data of 16 samples from the uppermost water column (depth $<30 \mathrm{~m}$ ) do not illustrate a positive correlation between DOC and ethylene concentrations as might be expected assuming photochemical build up of ethylene from DOC. Though it can not be ruled out that ethylene is derived from only a certain fraction of DOC, that might be identified by applying UV-oxidation techniques but not by high temperature oxidation (Ratte et al. 1995), the lack of enhanced concentrations in the uppermost water body during the day time 


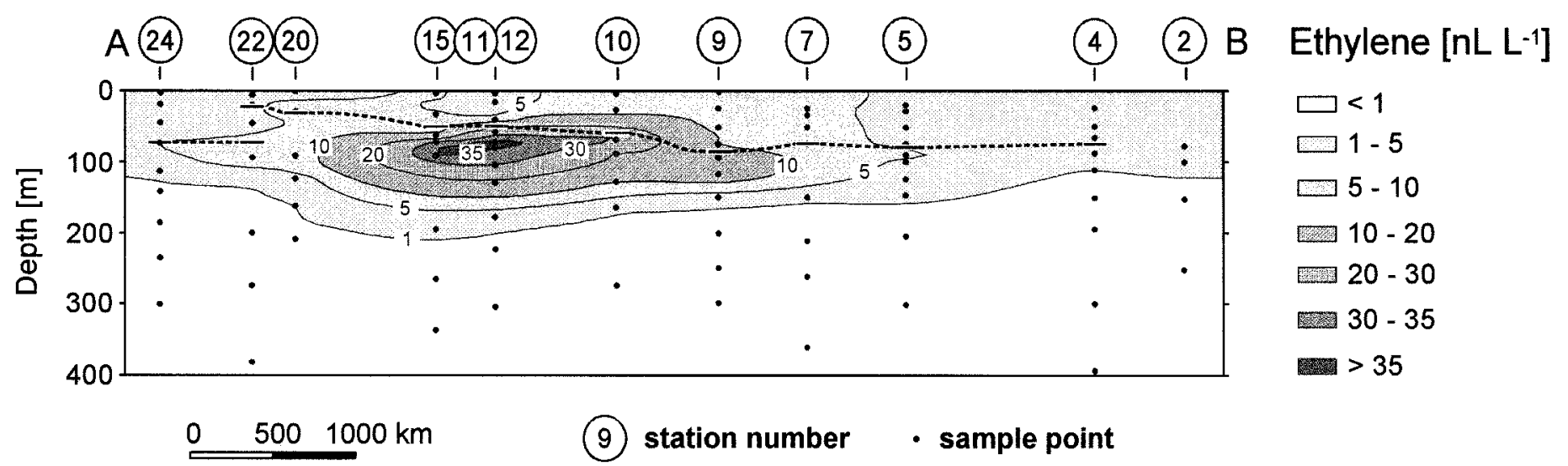

Figure 3. Concentrations of dissolved ethylene in the upper water column along the A-B profile (Figure 1). Station numbers are indicated above the profiles respectively. The upper edge of the pycnocline identified by density profiles (Sigma-T) is marked by white framed dashes. 


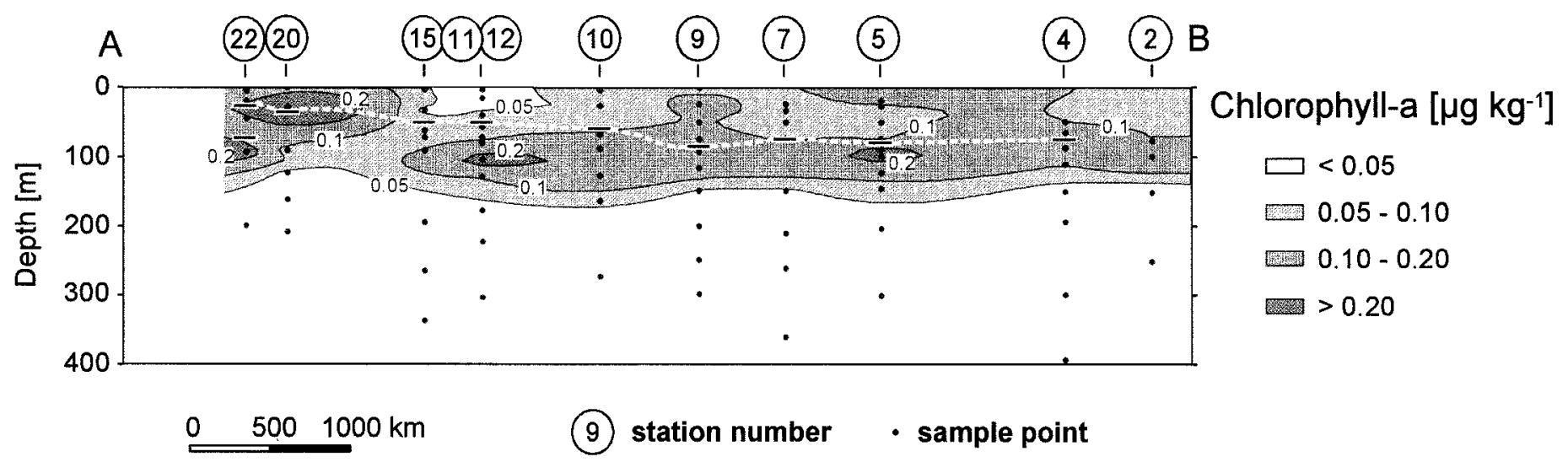

Figure 4. Concentrations of chlorophyll-a in the upper water column along the A-B profile (Figure 1). Station numbers are indicated above the profiles respectively. The upper edge of the pycnocline identified by density profiles (Sigma-T) is marked by white framed dashes. 


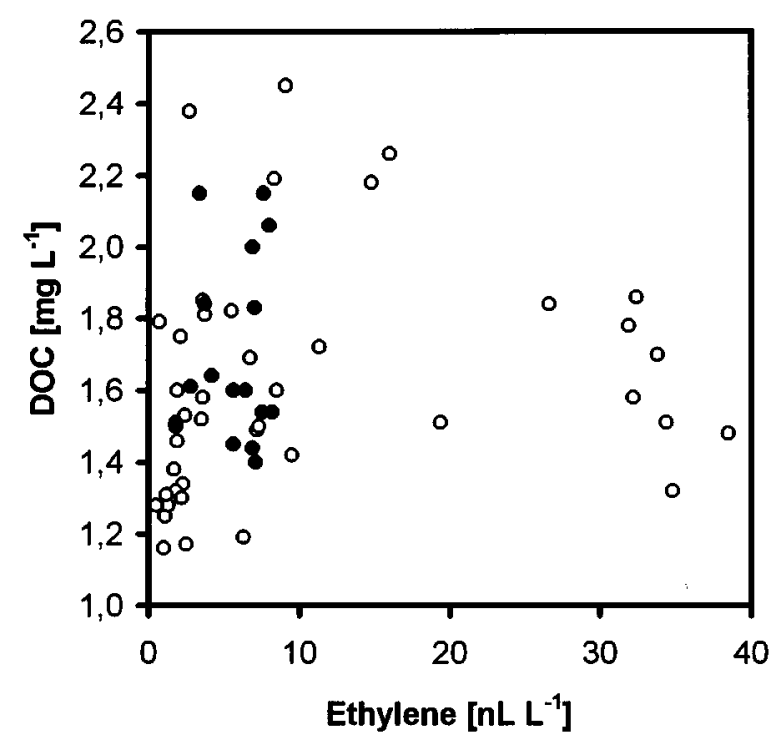

Figure 5. Concentrations of DOC and ethylene. Filled symbols represent samples from surface waters above $30 \mathrm{~m}$ depth. Samples are from stations 2, 4, 5, 7, 9, 10, 12, 15, 17, and 20.

in comparison to night time (Figure 7) also argues against a relevant light induced production of ethylene, at least for the studied area.

The relation between the vertical distributions of methane and ethylene and chlorophyll-a, nitrite, oxygen, and density, as observed in the central Atlantic, is exemplified by data from station 9 (Figure 6). Ethylene concentration steeply increased at the pycnocline to reveal a well defined maximum together with chlorophyll-a and oxygen maxima. No detectable ethylene was present below $250 \mathrm{~m}$ depth. Methane concentrations showed several smaller relative maxima. The two most prominent are below the pycnocline, where nitrite was also high, and at about $300 \mathrm{~m}$ depth. Thus, ethylene seems to be released predominantly at the pycnocline, while enhanced net production of methane appears to occur at several depths.

At $20: 39^{\circ} \mathrm{N}, 60: 55,5^{\circ} \mathrm{W}$ water samples were taken at 16:30 (station 15), 00:30 (station 17), and 08:30 (station 19) to study short-time variations. The profiles of dissolved methane differ between the stations with respect to both concentration and spatial distribution (Figure 7). In the afternoon (station 15), a relative minimum is observed between 25 and $60 \mathrm{~m}$ depth, followed by a steep increase reaching $73 \mathrm{~nL} \mathrm{~L}^{-1}$ at the pycnocline $(66 \mathrm{~m})$ and relatively high concentrations below $300 \mathrm{~m}$ depth. At 00:30, methane concentration increase from the surface $\left(44 \mathrm{~nL} \mathrm{~L}^{-1}\right)$ to reach $67 \mathrm{~nL} \mathrm{~L}^{-1}$ at $95 \mathrm{~m}$ depth, below the 


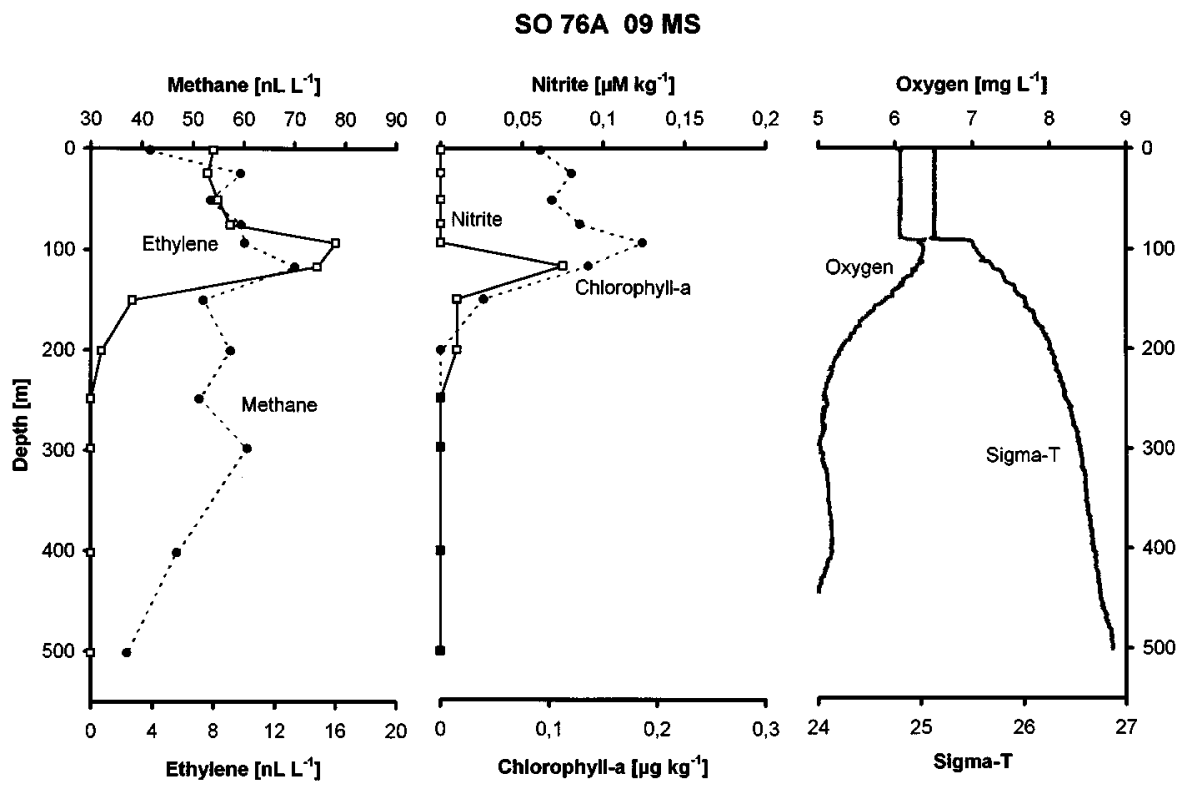

Figure 6. Concentrations of dissolved ethylene, dissolved methane, nitrite, chlorophyll-a, dissolved oxygen and density (sigma-T) in the upper water column at station 09 MS.

pycnocline. In the morning (station 19), highest concentrations are observed with maxima at 60 and $100 \mathrm{~m}$ depth.

The occurrence of multiple maxima together with diurnal variations in total concentrations and distribution might hint to zooplankton-related methane generation. Therefore, vertical diurnal migration of the zooplankton was tentatively traced by an ELAC echo sounder. During daytime, enhanced reflectance appeared between 0 and $100 \mathrm{~m}$ and, more pronounced, between $300 \mathrm{~m}$ and $450 \mathrm{~m}$ water depth. With sun down, between 18:30 and 19:30, the latter zone moves upward to result in one distinct horizon of high reflectance in the upper $100 \mathrm{~m}$ of the water column that persists until sun rise, when within one hour (06:30 to 07:30) the day situation is again established. We suggest that at least a considerable part of the zooplankton lives in the upper $100 \mathrm{~m}$ of the water column during night and migrates to stay below $300 \mathrm{~m}$ depth during day time. The presence of the zooplankton in more shallow horizons during night might be documented by enhanced methane concentrations above $150 \mathrm{~m}$ depth and diminished concentrations below $200 \mathrm{~m}$ depth as observed in the morning station (19). During day time, migration of zooplankton probably results in a methane increase below $300 \mathrm{~m}$ depth and a decrease in the upper water column. This situation is illustrated by station 15 .

No considerable short-time variation was observed for the distribution and concentration of ethylene in the upper water column (Figure 7). 


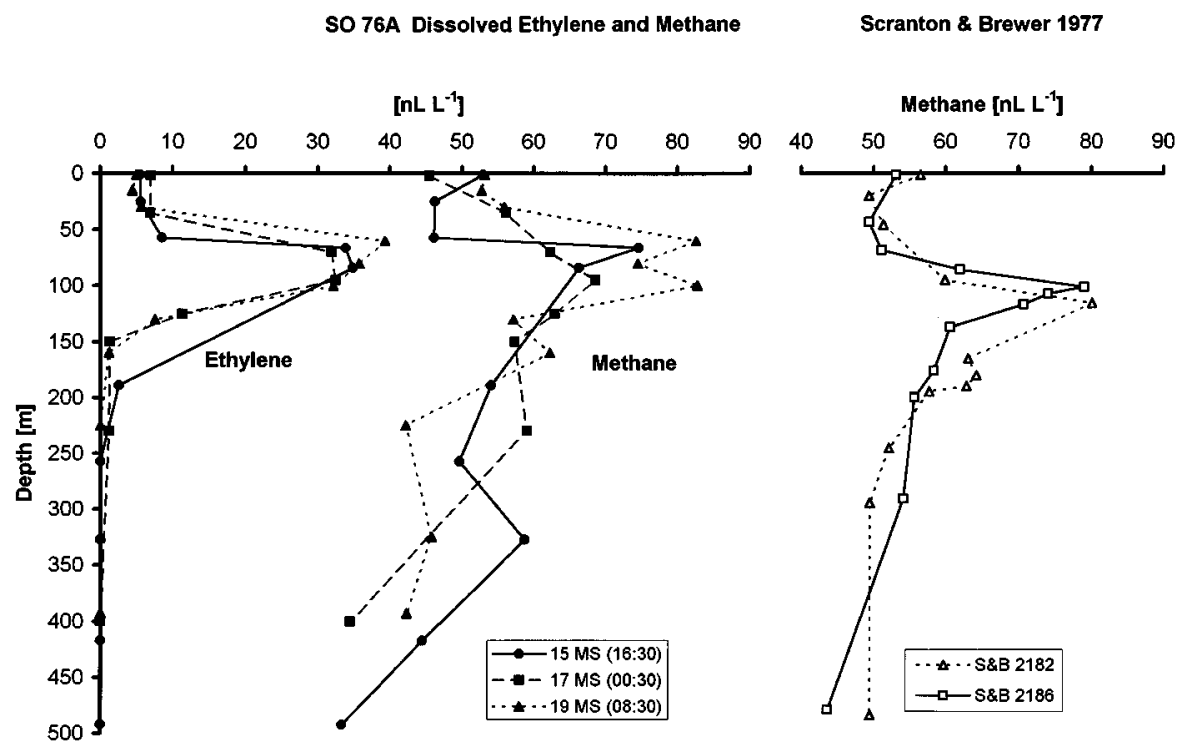

Figure 7. Short-time variations of dissolved methane and ethylene in the upper water column at $20: 39^{\circ} \mathrm{N}, 60: 55,5^{\circ} \mathrm{W}$.

Methane in surface water varied between 96 and $134 \%$ saturation with an average of $116.8 \%$ saturation The resulting flux of methane into the atmosphere varies between the stations from -0.19 to $2.66 \mu \mathrm{g} \mathrm{m}^{-2} \mathrm{~h}^{-1}$ giving an average flux of $0.82 \mu \mathrm{g} \mathrm{m}^{-2} \mathrm{~h}^{-1}$ (Figure 8), only slightly below the value of $1.32 \mu \mathrm{g} \mathrm{m}^{-2} \mathrm{~h}^{-1}$ calculated accordingly by Bange et al. (1994) for the Atlantic.

Flux rates of ethylene, calculated like those for methane and using the same Schmidt number correction, but neglecting atmospheric concentrations (Plass et al. 1992; Plass-Dülmer et al. 1995), range between 0.41 and $1.35 \mu \mathrm{g}$ $\mathrm{m}^{-2} \mathrm{~h}^{-1}$ with a mean flux of $0.83 \mu \mathrm{g} \mathrm{m}^{-2} \mathrm{~h}^{-1}$ (Figure 8).

\section{Discussion}

Methane production in oxygenated sea water is still a matter of debate. As all known methanogenic bacteria are strict anaerobes, various pathways of methane production coupled to anoxic microenvironments occurring in faecal pellets, digestion tracts of higher organisms, dead cells or organic aggregates have been emphasised.

Examining the presence of methanogenic bacteria in various suspended particles from the oxygenated water column of the western Mediterranean Sea, Marty (1993) found bacteria able to produce $\mathrm{CH}_{4}$ through different 

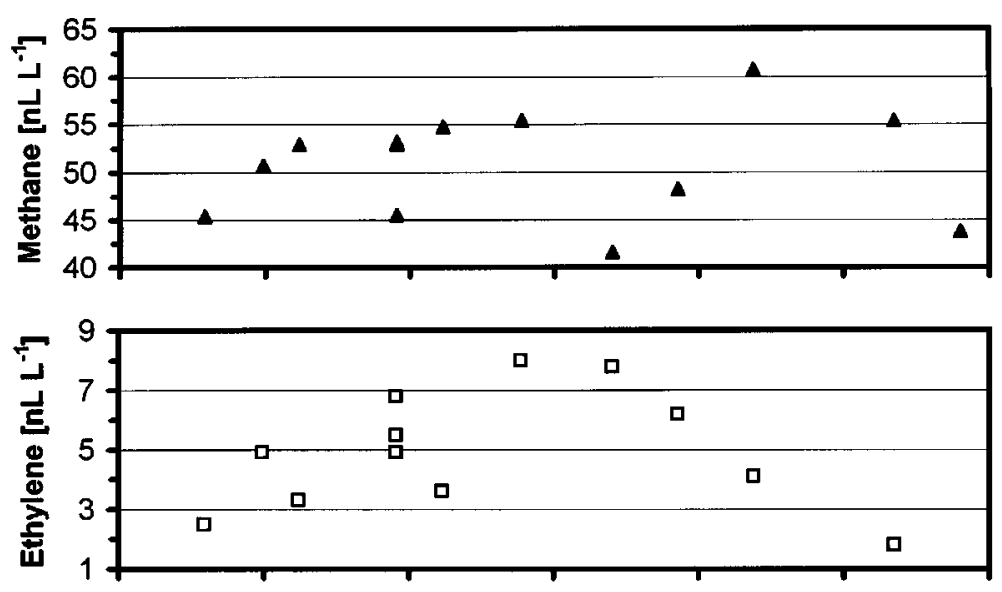

a Ethylene $\triangle$ Methane

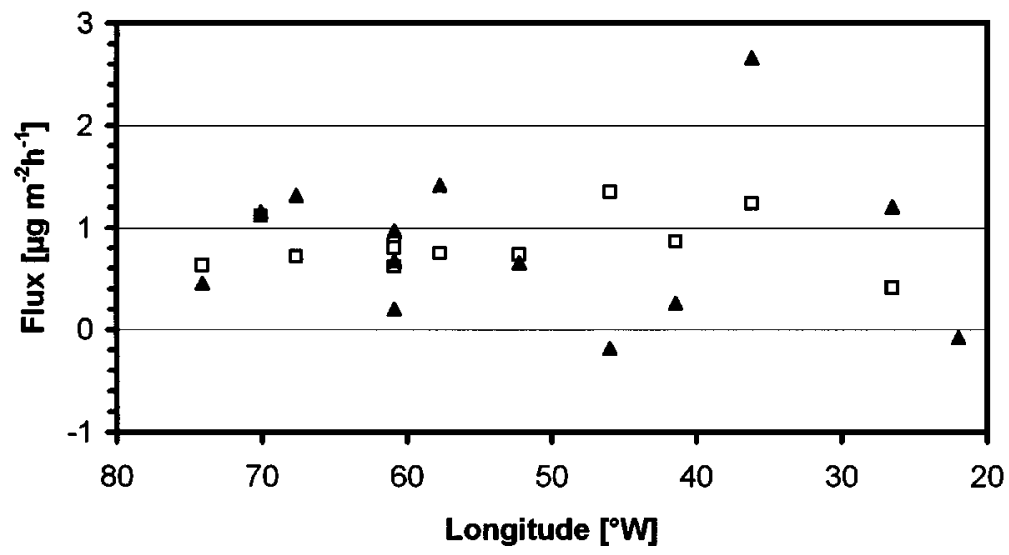

Figure 8. Concentrations of dissolved methane (top) and ethylene (centre). Bottom: Flux rates from the ocean into atmosphere for methane and ethylene (Not calculated for ethylene at station 2, as no measurements were done for samples of the upper $25 \mathrm{~m}$ of the water column).

methanogenic pathways including the use of methylamines. His results suggest that these bacteria originate from the digestive tracts of zooplankton and survive in anoxic suspended particles. Grazing experiments also support the idea of zooplankton mediated methane production in oxygenated sea water sufficient to maintain the observed oceanic subsurface $\mathrm{CH}_{4}$ maxima (De Angelis \& Lee 1994). These laboratory experiments additionally indicate methane production to depend on the respective zooplankton species rather than on the phytoplankton species being grazed. The authors supposed, that methanogenesis is primarily related to bacteria being capable of using sub- 
strates non-competitive to sulphate reducers like methylamines and which therefore do not require a sulphate depleted milieu. Karl and Tilbrook (1994) favour degassing from faecal pellets of methane produced in the digestive tracts of zooplankton as major source of methane in surface waters. They calculated that this process would be able to renew the methane inventory of the upper water column within 50 days without any additional sources or production within the faecal pellets. Scranton and Brewer (1977) suggested that methane might be a by-product of algael metabolism. Observations of a positive correlation between enhanced methane concentrations and ATPmaxima (Traganza et al. 1979) or chlorophyll- and ATP-maxima (Brooks \& Sackett 1973) correspond with these explanations. Sieburth (1988) showed the coexistence of bacterial methanogenesis and methane oxidation in oxygenated sea water in laboratory experiments. He hypothesised the existence of a methanogenic bacterial consortium that can create reduced microniches in the oxygenated sea water and produce methane (Sieburth 1987).

Methane production by a microbial consortium, capable of introducing anoxic, methanogenic conditions in organic macroparticles - ocean snow, flocks, agglomerates, faecal pellets - (Sieburth 1987; Marty 1993; De Angelis \& Lee 1994), or methane production only by degassing of faecal pellets from zooplankton as assumed by Karl and Tilbrook (1994), could be responsible for the observed methane enrichment at the pycnocline where particles are concentrated. The deeper maxima might be related to zooplankton and, in the case of the Caribbean, of lateral transport from water having gained methane from shelf sediments. Extraordinarily high methane concentrations up to $236 \mathrm{~nL} \mathrm{~L}^{-1}$ were observed at a near shore station located close to Grenada (Scranton \& Brewer 1977) and are assumed to reflect the influence of anoxic sediments in the coastal zone. Their estimations of the lateral methane transport from nearshore methane enriched waters to the open ocean suggest that this mechanism might supply some methane to the open ocean maximum, but in situ methanogenesis is clearly of considerable importance.

However, none of these mechanisms alone can satisfactorily explain the methane profiles we found in this study. Comparison with former investigations suggest that the processes controlling methane concentrations in the upper water column have not considerably changed during the last 20 years, at least for the subtropical western Atlantic. Two vertical methane profiles measured in February 1975 by Scranton and Brewer (1977), located close to our stations 15,17 and $19\left(2182\right.$ at $19^{\circ} 02^{\prime} \mathrm{N} ; 65^{\circ} 59^{\prime} \mathrm{W}, 2186$ at $18^{\circ} 59^{\prime} \mathrm{N}$; $61^{\circ} 16^{\prime} \mathrm{W}$ ), agree quite well with our results showing a maximum at about 100 $\mathrm{m}$ depth and enhanced concentrations at about $170 \mathrm{~m}$ depth (Figure 7). Also the methane flux into atmosphere, calculated by these authors to be $1.53 \mu \mathrm{g}$ $\mathrm{m}^{-2} \mathrm{~h}^{-1}$ at station 2186 , is similar to our estimates. 
Strong regional variations of ethylene concentrations in surface waters are observed in several studies of various marine areas including the Atlantic (Swinnerton \& Lamontagne 1974; Lamontagne et al. 1974; Plass et al. 1992; Plass-Dülmer et al. 1993, 1995). Investigations by Swinnerton and Lamontagne (1974) of samples from the Gulf of Mexico, the Caribbean Sea, the Atlantic, and the Pacific revealed mean concentrations for ethylene of 4.8 $\mathrm{nL} \mathrm{L}^{-1}$. A profile measured near Barbados in April $1969\left(13^{\circ} 13^{\prime} \mathrm{N} ; 59^{\circ} 07^{\prime} \mathrm{W}\right.$, about $9^{\circ}$ north of our stations 12 and 15) showed a broad peak between 20 and $120 \mathrm{~m}$ depth and the highest concentrations of all reported Atlantic stations $\left(13 \mathrm{~nL} \mathrm{~L}^{-1}\right.$ at about $80 \mathrm{~m}$ depth) while a profile from $30^{\circ} 14^{\prime} \mathrm{N} ; 70^{\circ} 10^{\prime} \mathrm{W}$, sampled in May 1971, revealed no distinct maximum and concentrations below $3 \mathrm{~nL} \mathrm{~L}^{-1}$. Together, these results are consistent with what we observed about 20 years later. Vertical hydrocarbon profiles in the Gulf of Mexico show a sharp ethylene maximum (>11 $\left.\mathrm{nL} \mathrm{L}^{-1}\right)$ at about $50 \mathrm{~m}$ depth located above a much broader methane enriched horizon (Brooks \& Sackett 1973). Thus, the position of the ethylene maximum above the methane maximum we observed might be a common feature that points to distinct processes controlling the concentrations of these hydrocarbons.

Plass-Dülmer et al. (1993) calculated a mean ethylene emission rate into the atmosphere for the Atlantic between $35^{\circ} \mathrm{N}$ and $35^{\circ} \mathrm{S}$ of $0.4 \mu \mathrm{g} \mathrm{m}^{-2} \mathrm{~h}^{-1}$ with highest rates reaching $0.98 \mu \mathrm{g} \mathrm{m}^{-2} \mathrm{~h}^{-1}$. The earlier estimation based on atmospheric measurements in 1979 over the Atlantic from $48^{\circ} \mathrm{N}$ to $4^{\circ} \mathrm{S}$ gave $0.6 \mu \mathrm{g} \mathrm{m}^{-2} \mathrm{~h}^{-1}$ (Rudolph \& Ehhalt 1981). The mean flux of $0.83 \mu \mathrm{g} \mathrm{m}^{-2}$ $\mathrm{h}^{-1}$ found in this study is well within this range. Interestingly, areas where large ethylene concentrations occurred at the pycnocline are not characterised by enhanced emission rates (Figure 3 and 8), but even show relatively small surface water concentrations. This suggests that the ethylene stock in surface water is not primarily fed from deeper water or that enhanced consumption rates of ethylene are present in these areas.

Biological ethylene production is well known from higher plants. It is the only known gaseous phytohormone of higher plants, formed as a metabolic product of methionine. Ethylene production is also known from bacteria and fungi (Lynch \& Harper 1974; Primrose \& Dilworth 1976; Primrose 1977; Mansouri \& Bunch 1989: Nagahama et al. 1991). All these known biological ethylene forming processes require oxygen. The source of ethylene in ocean surface water is not unequivocally known. Brooks and Sackett (1973) suggest that ethylene in the Gulf of Mexico is associated with primary productivity. Lamontagne et al. (1974) assume variations of ethylene concentrations in the Pacific to be the result of biologic activity. Zang et al. (1993) found indications for ethylene production in the red algae Porphyra perforata. Wilson et al. (1970) described a considerable increase of $C_{2}$ to $C_{4}$ hydrocarbons 
over a period of time in an illuminated, bacteria-free culture of the diatom Chaetoceros galvestonensis. They also found a light induced production of $\mathrm{C}_{2}$ - and $\mathrm{C}_{3}$-alkenes from DOC in sterilised sea water. Similar results were obtained by Ratte et al. (1993) who suggests a two-step production mechanism for alkenes: firstly release of dissolved organic matter (DOM), probably from algae, secondly photochemical transformation of DOM-constituents into alkenes. Lee and Baker (1992) observed a considerable increase of dissolved ethylene by exposure of estuarine water to sunlight. These authors ascribe ethylene production mainly to particulate matter, whereby photodecomposition of polyunsaturated fatty acids plays a significant role beside the biological production by phytoplankton. Plass-Dülmer et al. (1995), who compiled most of the available data on ethylene in ocean waters, note that ethylene concentrations are not correlated with solar radiation, chlorophyll-a, primary productivity, water temperature, latitude, or the proximity of coastlines, and suppose that wind speed, insulation and the concentration and contribution of DOC might have an impact on NMHC concentrations.

The appearance of ethylene found in the study is restricted to the upper $270 \mathrm{~m}$ of the water column showing a strong regional but no diurnal variability. Generally, ethylene concentrations are enhanced directly below the pycnocline and coincide with chlorophyll-a maxima, whereby the chlorophyll maximum appeared to be slightly below the ethylene maximum during the night. However, there is no linear correlation between the amount of chlorophyll-a and ethylene concentration throughout the studied area. Concerning ethylene concentrations in surface water, the lack of diurnal variation and of a positive correlation between DOC and ethylene concentrations indicate no relevant light induced production from DOC. Analogous to what is known from higher plants and the observations by Wilson et al. (1970), ethylene production might not only vary between different species, but is probably also strongly related to the physiological state of the planktonic community. Taking into account the extension of the investigated area, an overall correlation between chlorophyll-a and ethylene concentrations is therefore not to be expected. Assuming an enhanced ethylene production of aged planktonic organisms, analogous to what is observed for higher plants, increased concentrations at the pycnocline are explainable. Alternatively, ethylene might be released during the microbiological degradation of organic material accumulated at the pycnocline.

\section{Conclusions}

Dissolved methane concentration varied in the upper water column not only regionally, but also and diurnally. The supersaturation of methane found 
in Atlantic surface water and the resulting methane flux from ocean to atmosphere of $0.82 \mu \mathrm{g} \mathrm{m}^{-2} \mathrm{~h}^{-1}$ correspond with the recent estimation by Bange et al. (1994). The increase of ethylene concentrations from surface water to maximal concentrations at about $100 \mathrm{~m}$ depth, together with the lack of increased concentrations in the uppermost water column during the daytime, argue against a predominating generation by photochemical processes. Calculated ethylene fluxes into the atmosphere range between 0.41 and 1.35 $\mu \mathrm{g} \mathrm{m}^{-2} \mathrm{~h}^{-1}$.

No simple relation is observed between ethylene and DOC concentrations and between the amount of chlorophyll-a and ethylene concentration throughout the studied area.

Diurnal variations within the water column are observed for dissolved methane but not in the case of dissolved ethylene.

The lack of ethylene below $300 \mathrm{~m}$ water depth indicates negligible release of ethylene at greater depth, e.g. by zooplankton or remineralisation of sinking organic matter, or that its production is balanced by degradation. However, deeper waters can be suggested to be no relevant source of ethylene.

Variations of methane and ethylene in the upper water column along the investigated section appear to be characteristic features that persist over extended time periods, at least tens of years.

The relative distributions of ethylene and methane throughout the water column indicate that net production of ethylene occurs predominantly at one relatively narrow depth level mostly associated with the pycnocline while the release of methane takes place at several horizons distributed over a wider range of the water column.

Methane enriched waters in the Caribbean, suggested to be influenced by methane released from sediments, do not show enhanced ethylene concentrations.

\section{Acknowledgements}

We thank the captain and the crew of RV SONNE for their skilled support. The authors are grateful to Cindy Lee for thoughtful comments and suggestions on this manuscript. Analytical and technical support by A. Reimer and $\mathrm{S}$. Beckmann is appreciated. Two anonymous reviewers and the editor are acknowledged for their suggestions to improve the manuscript. This work was funded by the Bundesminister für Bildung, Wissenschaft, Forschung und Technologie, grant 03F0015D. 


\section{References}

Atkinson LP \& Richards FA (1967) The occurrence and distribution of methane in the marine environment. Deep-Sea Res. 14: 673-684

Bange HW, Bartell UH, Rapsomanikis S \& Andreae MO (1994) Methane in the Baltic and North Seas and a reassessment of the marine emissions of methane. Global Biogeochem. Cycles 8: 465-480

Bonsang B, Kanakidou M, Lambert G \& Monfray P (1988) The marine source of $\mathrm{C}_{2}-\mathrm{C}_{6}$ aliphatic hydrocarbons. J. Atmos. Chem. 6: 3-20

Bonsang B, Martin D, Lambert G, Kanakidou M, Le Roulley JC \& Sennequier G (1991) Vertical distribution of non methane hydrocarbons in the remote marine boundary layer. $\mathrm{J}$. Geophys. Res. 96: 7313-7324

Brooks JM \& Sackett WM (1973) Sources, sinks, and concentrations of light hydrocarbons in the Gulf of Mexico. J. Geophys. Res. 78: 5248-5258

Brooks JM, Reid DF \& Bernard BB (1981) Methane in the upper water column of the northwestern Gulf of Mexico. J. Geophys. Res. 86: 11029-11040

Burke JrRA, Reid DF, Brooks JM \& Lavoie DM (1983) Upper water column methane geochemistry in the eastern tropical North Pacific. Limnol. Oceanogr. 28: 19-32

Chappellaz J, Blunier T, Raynaud D, Barnola JM, Schwander J \& Stauffer B (1993) Synchronous changes in atmospheric $\mathrm{CH}_{4}$ and Greenland climate between 40 and $8 \mathrm{ky}$ BP. Nature 366: 443-445

Cicerone RJ \& Oremland RS (1988) Biogeochemical aspects of atmospheric methane. Global Biogeochem. Cycles 2: 299-327

Conrad R \& Seiler W (1988) Influence of the surface microlayer on the flux of nonconservative trace gases $\left(\mathrm{CO}, \mathrm{H}_{2}, \mathrm{CH}_{4}, \mathrm{~N}_{2} \mathrm{O}\right)$ across the ocean-atmosphere interface. J. Atmos. Chem. 6: 83-94

Cynar FJ \& Yayanos A (1992) The distribution of methane in the upper waters of Southern California Bight. J. Geophys. Res. 97: 11269-11285

De Angelis MA \& Lee C (1994) Methane production during zooplankton grazing on marine phytoplankton. Limnol. Oceanogr. 39: 1298-1308

De Angelis MA \& Lilley MD (1987) Methane in surface waters of Oregon estuaries and rivers. Limnol. Oceanogr. 32: 716-722

Dlugokencky EJ, Lang PM, Masarie KA \& Steele LP (1994) Atmospheric $\mathrm{CH}_{4}$ records from sites in the NOAA/CMDL air sampling network. In: Boden TA, Kaiser DP, Sepanski RJ \& Stoss FW (Eds) Trends '93: A Compendium of Data on Global Change, ORNL/CDIAC65 (pp 274-350). Carbon Dioxide Information Analysis Center, Oak Ridge National Laboratory, Oak Ridge, Tenn., USA

Evans LV \& Trewavas AJ (1991) Is algal development controlled by plant growth substances? J. Phycol. 27: 322-326

Fengler G (1995) Zur Konzentration und Molekulargewichtsverteilung gelöster organischer Substanzen am Beispiel von gelöstem organischen Kohlenstoff. Analytische Methoden und ihre Anwendung. PhD Thesis, Universität Hamburg, Fachbereich Geowissenschaften, p 198

Greenberg JP, Zimmerman PR \& Haagenson P (1990) Troposheric hydrocarbon and CO profiles over the U.S. West Coast and Alaska. J. Geophys. Res. 95: 14015-14026

Jones RD \& Amador JA (1993) Methane and carbon monoxide production, oxidation, and turnover rates in the Caribbean Sea as influenced by the Orinoco River. J. Geophys. Res. 98: 2353-2359 
Karl DM \& Tillbrook BD (1994) Production and transport of methane in oceanic particulate organic matter. Nature 368: 732-734

Khalil MAK \& Rasmussen RA (1983) Sources, sinks, and seasonal cycles of atmospheric methane. J. Geophys. Res. 88: 5131-5144

Lamontagne RA, Swinnerton JW, Linnenbom VJ \& Smith WD (1973) Methane concentrations in various marine environments. J. Geophys. Res. 78: 5317-5324

Lamontagne RA, Swinnerton JW \& Linnenbom VJ (1974) $C_{1}-C_{4}$ hydrocarbons in the North and South Pacific. Tellus 26: 71-77

Lamontagne RA, Smith WD \& Swinnerton JW (1975) C1-C3 hydrocarbons and chlorophyll a concentrations in the equatorial Pacific ocean. In: Gibb JrTRP (Ed) Analytical Methods in Oceanography. Adv. Chem. Ser. 147: 163-171

Lee RF \& Baker J (1992) Ethylene and ethane production in an estuarine river: formation from the decomposition of polyunsaturated fatty acids. Mar. Chem. 38: 25-36

Lynch JM \& Harper SHT (1974) Formation of ethylene by a soil fungus. J. Gen. Microbiol. 80: $187-195$

Mansouri S \& Bunch AW (1989) Bacterial ethylene sythesis from 2-oxo-4-thiobutyric acid and from methionine. J. Gen. Microbiol. 135: 2819-2827

Marty DG (1993) Methanogenic bacteria in seawater. Limnol. Oceanogr. 38: 452-456

Michaelis W, Bönisch G, Jenisch A, Ladage S, Richnow HH, Seifert R \& Stoffers P (1990) Methane and ${ }^{3} \mathrm{He}$ anomalies related to submarine intraplate volcanic activities Mitt. Geol. Paläont. Inst. Univ. Hamburg 60: 117-127.

Nagahama K, Ogawa T, Fujii T, Tazaki M, Tanase S, Morino Y \& Fukuda H (1991) Purification and properties of an ethylene-forming enzyme from Pseudimonas syringae pv. phaseolicola PK2. J. Gen. Microbiol. 137: 2281-2286

Owens NJP, Law CS, Mantoura RFC, Burkill PH \& Llewellyn A (1991) Methane flux to the atmosphere from the Arabian Sea. Nature 354: 293-296

Plass C, Koppmann R \& Rudolph J (1992) Light hydrocarbons in surface water of the MidAtlantic. J. Atmos. Chem. 15: 235-251

Plass-Dülmer C, Kehdim A, Koppmann R, Johnen FJ \& Rudolph J (1993) Emission of light nonmethane hydrocarbons from the Atlantic into the atmosphere. Global Biochem. Cycles 7: $211-228$

Plass-Dülmer C, Koppmann R, Ratte M \& Rudolph J (1995) Light nonmethane hydrocarbons in seawater. Global Biogeochem. Cycles 9: 79-100

Plüger WL, Herzig PM, Becker KP, Deismann G, Schöps D, Lange J, Jenisch A, Ladage S, Richnow HH, Schulze T \& Michaelis W (1990) Discovery of hydrothermal fields at the Central Indian Ridge. Marine Mining 9: 73-86

Primrose SB (1977) Evaluation of the role of methional, 2-keto-4-methylthiobutyric acid and peroxidase in ethylene formation by Escherichia coli. J. Gen. Microbiol. 98: 519-528

Primrose SB \& Dilworth MJ (1976) Ethylene production by bacteria. J. Gen. Microbiol. 93: $177-181$

Rasmussen RA \& Khalil MAK (1984) Atmospheric methane in the recent and ancient atmospheres: Concentrations, trends, and interhemispheric gradient. J. Geophys. Res. 89: 11599-11605

Ratte M, Plass-Dülmer C, Koppmann R \& Rudolph J (1993) Production mechanism of $\mathrm{C}_{2}-$ $\mathrm{C}_{4}$ hydrocarbons in seawater: field measurements and experiments. Global Biogeochem Cycles 7: 369-378

Ratte M, Plass-Dülmer C, Koppmann R \& Rudolph J (1995) Horizontal and vertical profiles of light hydrocarbons in sea water related to biological, chemical and physical parameters. Tellus 47B: 607-623 
Rudolph J \& Ehhalt DH (1981) Measurements of $\mathrm{C}_{2}-\mathrm{C}_{5}$ hydrocarbons over the North Atlantic. J. Geophys. Res. 86: 11959-11964

Sawada S \& Totsuka T (1986) Natural and anthropogenic sources and fate of atmospheric ethylene. Atmos. Environ. 20: 821-832

Scranton MI \& Farrington JW (1977) Methane production in the Walvis Bay. J. Geophys. Res. 82: 4947-4953

Scranton MI \& Brewer PG (1977) Ocurrence of methane in the near-surface waters of the western subtropical North-Atlantic. Deep-Sea Res. 24: 127-138

Scranton MI \& Brewer PG (1978) Consumption of dissolved methane in the deep ocean. Limnol. Oceanogr. 23: 1207-1213

Sieburth J McN (1987) Contrary habitats for redox-specific processes: methanogenesis in oxic waters and oxidation in anoxic waters. In: Sleigh MA (Ed) Microbes in the Sea (pp 11-38). Ellis Horwood Limited and John Wiles and Sons

Sieburth J McN (1988) The trophic roles of bacteria in marine ecosystems are complicated by synergistic-consortia and mixotrophic-cometabolism. Progr. Oceanog. 21: 117-128

Stauffer B, Lochbronner E, Oeschger H \& Schwander J (1988) Methane concentration in the glacial atmosphere was only half that of the preindustrial Holocene. Nature 332: 312-314

Steele LP, Fraser PJ, Rasmussen RA, Khalil MAK, Conway TJ, Crawford AJ, Gammon RH, Masarie KA \& Thoning KW (1987) The global distribution of methane in the troposphere. L. Atmos. Chem. 5: 125-171

Steele LP, Dlugokencky EJ, Lang PM, Tans PP, Martin RC \& Masarie KA (1992) Slowing down of the global accumulation of atmospheric methane during the 1980s. Nature 358: 313-316

Stüben D, Stoffers P, Cheminee JL, Hartmann M, McMurtry G, Richnow HH, Jenisch A \& Michaelis W (1992) Manganese, methane, iron, zinc, and nickel anomalies in hydrothermal plumes from Teahitia and Mcdonald volcanoes. Geochim. Cosmochim. Acta 56: 3693-3701

Swinnerton JW \& Lamontagne RA (1974) Oceanic distribution of low-molecular-weight hydrocarbons. Environm. Sci. Technol. 8: 657-663

Traganza ED, Swinnerton JW \& Cheek CH (1979) Methane supersaturation and ATPzooplankton blooms in near-surface waters of the Mediterranean and the subtropical North Atlantic Ocean. Deep-Sea Res. 26: 1237-1245

Wilson DF, Swinnerton JW \& Lamontagne RA (1970) Production of carbon monoxide and gaseous hydrocarbons in seawater: relation to dissolved organic carbon. Science 168: 1577-1579

Zhang W, Yamane H \& Chapman DJ (1993) The phytohormone profile of the red alga Porphyra perforata. Botanica Marina 36: 257-266 